\title{
SELECTION OF OPTIMAL DIMENSIONS OF AIR HUMIDIFICATION SECTION IN MICROCLIMATE PREPARATION SYSTEM FOR GROWING OFENTOMOPHAGES
}

\author{
Valentyna Krutyakova ${ }^{1}$, Volodymyr Bulgakov ${ }^{2}$, Aleksandrs Adamovics ${ }^{3}$, Nonna Pishchanska ${ }^{1}$ \\ ${ }^{1}$ Engineering and Technology Institute "Biotechnica", Ukraine; \\ ${ }^{2}$ National University of Life and Environmental Sciences of Ukraine, Ukraine; \\ ${ }^{3}$ Latvia University of Life Sciences and Technologies, Latvia \\ semjons@apollo.lv
}

\begin{abstract}
When organising the air humidification process in entomological production premises, it is necessary to ensure a high level of the equipment efficiency with the minimisation of the non-productive water consumption and the reduction of the energy consumed during the process. There is proposed a variant of an improved compact heat and mass exchange equipment for a microclimate creation system in the entomological industrial premises, in which the humidification process of the air flow takes place by direct contact with water inside of regular packages with a developed system of channels. The most modern package elements are made on the basis of corrugated sheets. The purpose of the work is to determine the optimal dimensions of the humidification packages in the aspect of aerodynamics and the air humidification efficiency for the development of efficient humidification devices, applied in microclimate creation systems for the entomological production premises. New types of regular packages are used, formed from sheets that are characterised by a high degree of wettability due to the structure of materials or a special surface geometry. Optimal geometrical dimensions of the package in the humidification device are determined taking into account aerodynamics and the efficiency of air humidification, and ensuring minimisation of the water costs as well. Experimental tests were carried out on the effect of the layout dimensions of regular packages for the humidification devices used in the air conditioning systems. A comparative assessment of the ratio of the layout dimensions of the regular structured packages is given. The depth of the humidification package should not exceed $0.5 \mathrm{~m}$. Packages, made from corrugated RN plates or GLASdek polymer sheets, are more preferable than PET packages.
\end{abstract}

Keywords: entomological production, microclimate, temperature, humidity, device.

\section{Introduction}

Raising the environmental safety of agricultural production is directly related to the development of biotechnologies for the production and use of biological plant protection products, based on highly efficient populations of entomophages. Particularly pending the developing biotechnologies are for the organic farming enterprises, where agricultural technologies for growing products imply a total ban on the use of pesticides and other agrochemicals. Industrial production (breeding) of entomophages includes a complex of engineering and biological solutions, including optimal microclimate and air humidity in the production premises [1-5].

When organising the air humidification process in entomological production premises, it is necessary to ensure a high level of the equipment efficiency with the minimisation (or absence) of the non-productive water consumption and the reduction of the energy consumed during the process [6-8]. For this purpose, new types of regular packages (RN) are investigated in the contact humidification devices, distinguished by a high level of wettability due to the materials used, or an original surface geometry.

Studies in the optimisation of the geometry of the package elements of a film apparatus were carried out in Germany (the Sulzer firm), in Italy, in Sweden (the Munters firm), and other countries. It was found that for the film countercurrent devices, optimal are the arranged symmetrical packages with vertical channels, which periodically come into contact with the adjacent channels.

The most modern package elements are made on the basis of corrugated sheets. The most widely used are the elements of the Munters firm (Sweden). These are alternating corrugated and flat sheets that form closed channels, which, in turn, is a significant disadvantage. The sheets are technological, and they can be made from low-strength materials [8;9].

The purpose of the work is to determine the optimal dimensions of the humidification packages in the aspect of aerodynamics and the air humidification efficiency for the development of efficient humidification devices, applied in microclimate creation systems for the entomological production premises. 


\section{Materials and Methods}

The following materials are proposed for consideration as working surfaces of regular packages in the microclimate creation system for growing of entomocultures:

- ribbed miplast plates (two sizes) - RN I, and RN II (Fig. 1a);

- $\quad$ specially profiled PET sheets (two sizes) - RN III, and RN IV (Fig. 1b);

- corrugated polymer sheets "GLASdek3" ("Munters", Sweden) - RN V (Fig. 1c);

- PVC corrugated plates (two sizes, the Netherlands) - RN VI, and RN VII (Fig. 1d).

One of the main factors affecting the optimal overall dimensions of the humidification packages is the speed of the air movement in the effective cross section of the package $v$ at a particular flow rate $G_{\theta}$. The layout of the package was varied by varying its cross-section $F_{f . s}$ anddepth $L$ (Fig. 2) [10].

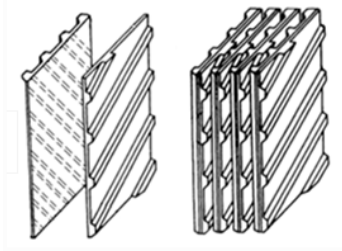

a)

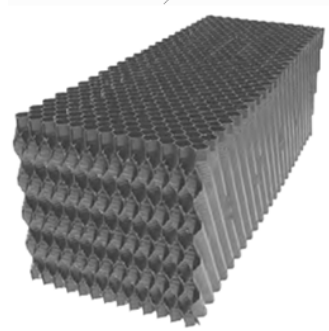

c)

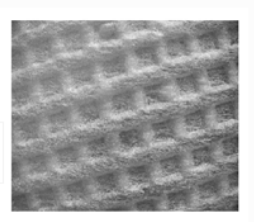

b)

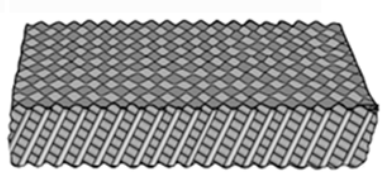

d)

Fig. 1. Types of RN studied: a - RN I, and RN II (miplast); b - RN III, and PN IV (PET); c - RN V (GLASdek 3); d - RN VI, and RN VII (PVC)

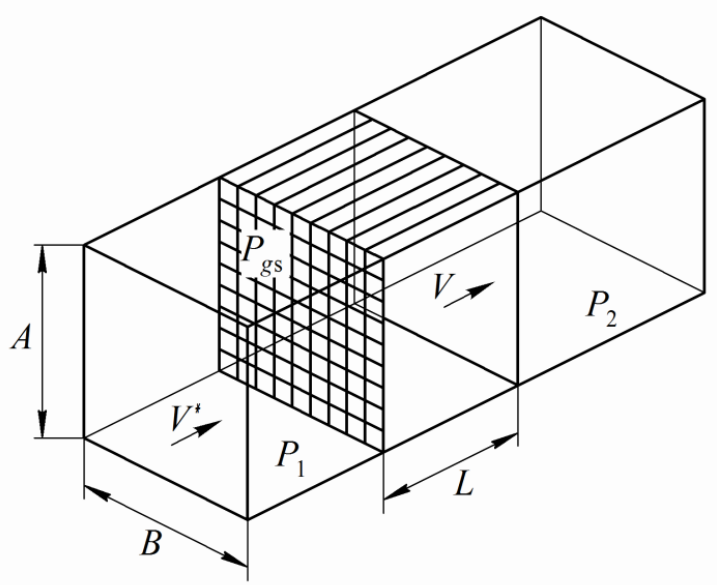

Fig. 2. Geometrical and aerodynamic characteristics of package: $F$ - cross-section of the package, $F=A \cdot B, \mathrm{~m}^{2} ; L$-depth of the package, $\mathrm{m} ; V^{\prime}$ - speed in the air channel, $\mathrm{m} \cdot \mathrm{s}^{-1} ; V$ - speed in the effective section of the package, $\mathrm{m} \mathrm{s}^{-1} ; \Delta P=P_{1}-P_{2}$ - aerodynamic resistances of the package, $\mathrm{Pa}$

Variations in the dimensions $A, B$ and $L$ make it possible to obtain their optimum correlation in the aspect of a maximum assimilating capacity of air with respect to humidity and a decrease in the aerodynamic resistance of the package.

As a rule, when calculating the humidification packages, the ultimate goal is to determine the surface area $F_{n}$, which will allow obtaining the required final parameters of the air subjected to the heat and humidity treatment with a certain mass flow rate $G_{6}$. 
Determination of the optimal dimensions of the $\mathrm{RN}$ was made in the following order (formulas 1 to 11 ).

The heat and humidity characteristic of the premises $\varepsilon, \mathrm{kJ} \cdot \mathrm{kg}^{-1}$ :

$$
\varepsilon=\frac{h_{v}^{\text {out }}-h_{v}^{\text {in }}}{d_{v}^{\text {out }}-d_{v}^{\text {in }}},
$$

where $h_{v}^{\text {in }}, h_{v}^{\text {out }}$ - moisture content of the air at the inlet and the outlet from the package, respectively, $\mathrm{kg} \cdot \mathrm{kg}^{-1}$.

The evaporation rate (mass exchange), $\mathrm{m} \mathrm{s}^{-1}$ :

$$
\beta=\frac{S h \cdot D}{L},
$$

where $S h$-Sherwood criterion;

$D$ - diffusion coefficient, $\mathrm{m}^{2} \mathrm{~s}^{-1}$;

$L$ - characteristic dimension, $\mathrm{m}$.

Air density, $\mathrm{kg} \cdot \mathrm{m}^{-3}$ :

$$
\rho_{v}=\frac{353}{\left(273+\frac{t_{v}^{\text {in }}+t_{v}^{\text {out }}}{2}\right)}
$$

where $t_{v}^{\text {in }}, t_{v}^{\text {out }}$ - air temperature at the inlet and the outlet from the package, respectively, ${ }^{\circ} \mathrm{C}$.

The partial air pressure at the inlet, Pa:

$$
P_{v}^{i n}=\frac{d_{v}^{i n}}{0.622+d_{v}^{i n}} .
$$

The partial air pressure at the outlet, Pa:

$$
P_{v}^{\text {out }}=\frac{d_{v}^{\text {out }}}{0.622+d_{v}^{\text {out }}} .
$$

The required amount of the evaporated water $G_{\mathrm{i}}, \mathrm{kg} \cdot \mathrm{s}^{-1}$ :

$$
G_{i}=G_{v}\left(d_{v}^{\text {out }}-d_{v}^{\text {in }}\right) .
$$

The cross-section $F$ of the package, $\mathrm{m}^{2}$ :

$$
F=\frac{G_{v}}{\rho_{v} \cdot v} .
$$

Using the heat-humidity characteristic $\varepsilon$, we calculated the required water temperature $t_{w}$ and the partial pressure $P_{p}$ in the saturation line.

The package area to ensure the specified conditions $F_{n}, \mathrm{~m}^{2}$ :

$$
F_{n}=\frac{G_{i}}{\beta \cdot\left(P_{P}-\frac{P_{v}^{\text {in }}-P_{v}^{\text {out }}}{2}\right)} .
$$

The volume of the package is defined as $V_{n}, \mathrm{~m}^{3}$ :

$$
V_{H}=F_{H} F_{v}^{-1} \text {, }
$$

where $F_{v}$-specific surface area of the package, $\mathrm{m}^{2} \mathrm{~m}^{-3}$.

The effective cross section area of the package is determined $F_{g . s}, \mathrm{~m}^{2}$ : 


$$
F_{g . s}=\frac{G_{v}}{\rho_{v}} \cdot v,
$$

where $\rho_{v}$-air density, $\mathrm{kg} \cdot \mathrm{m}^{-3}$.

Then, the depth of the package $L, \mathrm{~m}$ :

$$
L=\frac{V_{n}}{F_{g . s}} .
$$

\section{Results and discussion}

Investigations were conducted to analyse the variations in the temperature, moisture content, and aerodynamic resistance of the $\mathrm{PH}$, depending on the depth of the package (Fig. 3-5). The coefficient of variation of the measured parameters did not exceed $18 \%$.

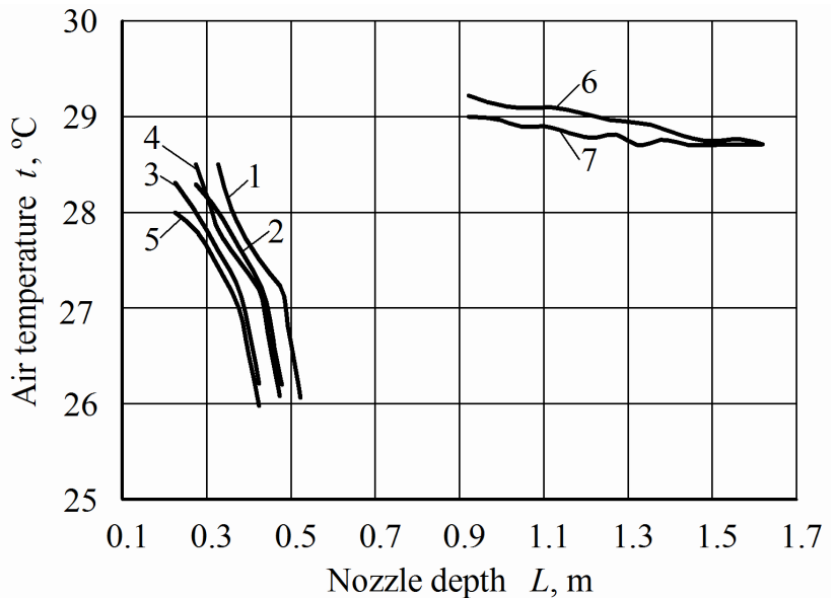

Fig.3. Dependence of variations in air temperature $t$ on depth of package $\boldsymbol{L}$ :

$$
1 \text { - RN I;2 - RN II;3 - RN III;4 - RN IV;5 - RN V;6 - RN VI; } 7 \text { - RN VII }
$$

As it can be seen from Fig. 3, variations in the air temperature $t$ have almost linear dependence on the depth of the package $L$. When increasing the depth of the package by every $0.1 \mathrm{~m}$, the temperature increment is about $1^{\circ} \mathrm{C}$ or $2.5 \%$.

A similar linear dependence upon the depth of the package $L$ is displayed by the change in the air moisture content $\Delta d$ (Fig. 4). Increasing the depth of the package by every $0.1 \mathrm{~m}$, the increment of the moisture content is about $10 \%$.

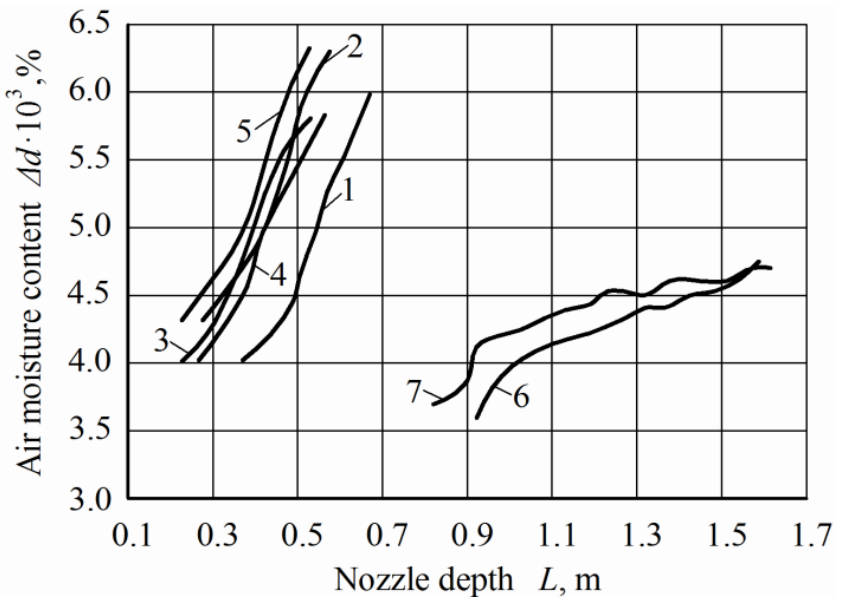

Fig.4. Dependence of air moisture content $\Delta d$ on depth of package $L$ :

1 - RN I;2 - RN II;3 - RN III;4 - RN IV;5 - RN V;6 - RN VI; 7 - RN VII 
Dependence of the change in the air aerodynamic resistance $\Delta P$ upon the depth of the package $L$, in contrast to the temperature and the moisture content, has a non-linear relationship (Fig. 5). Thus, the depth of the package increasing to $L=0.3 \mathrm{~m}$, the increment $\Delta P$ is $120 \%$, and at $L=0.4 \mathrm{~m}$, the increment $\Delta P$ reaches $290 \%$. In accordance with the results of the analysis of all experimental investigations, engineering recommendations have been formulated for the geometry of the PH. The presented recommendations correspond to the specific air flow rate $G_{\mathrm{g}}=0.1 \mathrm{~kg} \cdot \mathrm{s}^{-1}$ (Table 1).

All characteristics meet the same initial conditions (Table 2).

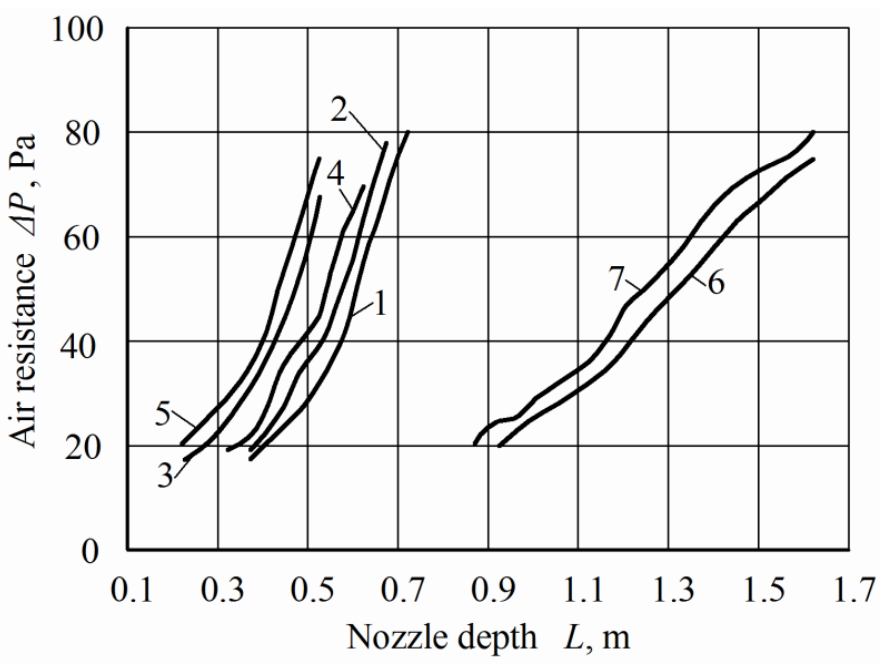

Fig. 5. Dependence of change in air aerodynamic resistance $\Delta P$ upon depth of package $L$ : 1 - RN I;2 - RN II;3 - RN III;4 - RN IV;5 - RN V;6 - RN VI; 7 - RN VII

Recommended characteristics of packages for the specific air flow rate $G_{\mathrm{g}}=0.1 \mathrm{~kg} \cdot \mathrm{s}^{-1}$

\begin{tabular}{|c|c|c|c|c|c|c|c|}
\hline \multirow{2}{*}{ Parameters } & \multicolumn{7}{|c|}{ Type of the package } \\
\cline { 2 - 8 } & RNI & RNII & RNIII & RNIV & RNV & RNVI & RN VII \\
\hline Volume of the package, $\mathrm{m}^{3}$ & 0.031 & 0.026 & 0.029 & 0.034 & $\begin{array}{c}0.02 \\
8\end{array}$ & 0.114 & 0.110 \\
\hline Depth of the package, $\mathrm{m}$ & 1.26 & 1.1 & 1.23 & 1.14 & 1.19 & 4.84 & 4.3 \\
\hline Speed of the air flow, $\mathrm{m} \cdot \mathrm{s}^{-1}$ & 3.6 & 3.6 & 3.6 & 3.6 & 3.6 & 3.6 & 3.6 \\
\hline Initial water temperature, ${ }^{\circ} \mathrm{C}$ & 22 & 22 & 22 & 22 & 22 & 22 & 22 \\
\hline Amount of water, $\mathrm{kg}$ & 0.895 & 1.231 & 0.999 & 1.281 & 1.38 & 0.729 & 0.659 \\
\hline $\begin{array}{c}\text { Amount of water per } 1 \mathrm{~m}^{2} \text { of } \\
\text { the package, } \mathrm{kg}\end{array}$ & 0.057 & 0.073 & 0.063 & 0.074 & $\begin{array}{c}0.08 \\
7\end{array}$ & 0.046 & 0.044 \\
\hline Water evaporation time, $\mathrm{h}$ & 0.834 & 112 & 0.925 & 1.06 & 1.27 & 0.675 & 0.614 \\
\hline Aerodynamic resistance, $\mathrm{Pa}$ & 75.2 & 77.1 & 76.1 & 76.9 & 78.5 & 19.4 & 19.2 \\
\hline
\end{tabular}

Table 2

Initial conditions for the determination of optimal characteristics of the investigated packages

\begin{tabular}{|l|c|}
\hline \multicolumn{1}{|c|}{ Parameters } & Values \\
\hline Inlet air temperature, ${ }^{\circ} \mathrm{C}$ & 30 \\
\hline Humidity content of the inlet air, $\mathrm{kg} \cdot \mathrm{kg}^{-1}$ & 0.01 \\
\hline Enthalpy of the inlet air, $\mathrm{kJ} \cdot \mathrm{kg}^{-1}$ & 55.77 \\
\hline Relative humidity of air at the inlet, \% & 0.345 \\
\hline Partial air pressure at the inlet, $\mathrm{kPa}$ & 1.58 \\
\hline
\end{tabular}

Summary data have been formed for the typical dimensions of the modules of the humidification section depending on the efficiency of the air conditioning system for each of the package types with the preset initial parameters (Table 3). 
Typical dimensions of the air humidification section

Table 3

\begin{tabular}{|c|c|c|c|c|c|c|c|}
\hline \multirow{2}{*}{$\begin{array}{c}\text { Nominal } \\
\text { capacity, }^{\mathbf{3}} \mathbf{h}^{-\mathbf{1}}\end{array}$} & \multicolumn{7}{|c|}{ Volume of the package, $\mathbf{~}^{\mathbf{3}}$} \\
\hline & RN I & RNII & RN III & RN IV & RN V & RN VI & RN VII \\
\hline 500 & 0.049 & 0.048 & 0.049 & 0.048 & 0.048 & 0.195 & 0.195 \\
\hline 1000 & 0.097 & 0.095 & 0.096 & 0.093 & 0.093 & 0.379 & 0.379 \\
\hline 2000 & 0.196 & 0.192 & 0.196 & 0.184 & 0.189 & 0.769 & 0.769 \\
\hline 5000 & 0.489 & 0.478 & 0.487 & 0.466 & 0.473 & 1.920 & 1.920 \\
\hline 7000 & 0.690 & 0.662 & 0.680 & 0.650 & 0.659 & 2.680 & 2.680 \\
\hline 10000 & 0.981 & 0.955 & 0.972 & 0.943 & 0.943 & 3.820 & 3.820 \\
\hline 12000 & 1.180 & 1.140 & 1.170 & 1.140 & 1.130 & 4.590 & 4.590 \\
\hline 15000 & 1.480 & 1.430 & 1.460 & 1.420 & 1.410 & 5.740 & 5.740 \\
\hline 20000 & 1.970 & 1.890 & 1.950 & 1.790 & 1880 & 7.660 & 7.660 \\
\hline
\end{tabular}

\section{Conclusions}

1. The obtained theoretical and experimental data may be used in the development of a compact heat-and-mass exchange equipment of the microclimate preparation system for entomological production (in particular, on the basis of RN air humidifiers).

2. The depth of the humidification package should not exceed $0.5 \mathrm{~m}$. Further increase in depth is not purposeful, since, with a slight effect of the change in the temperature and moisture content, the aerodynamic resistance increases significantly, which leads to increased operating costs of the microclimate creation systems. Packages, made from corrugated RN plates or GLASdek polymer sheets, are more preferable than PET packages.

3. Dependence of the change in the air aerodynamic resistance $\Delta P$ upon the depth of the package $L$, in contrast to the temperature and the moisture content, has a non-linear relationship. The depth of the package increasing to $L=0.3 \mathrm{~m}$, the increment $\Delta P$ is $120 \%$, and at $L=0.4 \mathrm{~m}$, the increment $\Delta P$ reaches $290 \%$.

\section{References}

[1] Bakthavatsalam N., Tandon P.L.Interactions between plant chemicals and the entomophages.Pestology, 29 (11), 2005, pp. 17-31.

[2] Gautam R.D., Tesfaye A. Potential of green lacewing, Chrysoperla carnea (Stephens), in crop pest management. New Agriculturist, 13 (1-2), 2002, pp. 147-158.

[3] Usman A., Naeem M., Salihah Z., Ulhaq M., Saeed M.Q. Effect of different adult diets on Chrysoperla carneaSteph. (chrysopidae, neuroptera), a biological control agent. Sarhad Journal of Agriculture, 22 (1), 2006, pp. 37-40

[4] Targonya V., Yavoriv V. To the question of using the expert system of multifactor analysis for the choice of the development of biotechnological processes and equipment. J. Machinery and Technologies for Agro-industrial Complex, 10 (13), 2010, pp. 31-34

[5] Harsimranjit S., Sharma N. A review of fuzzy based expert system in agriculture. International Journal of Engineering Sciences \& Research Technology, 3 (7), 2014, pp. 912-915.

[6] Marteijn R.C.L., Jurrius O., Dhont J., De Gooijer C.D., Tramper J., Martens D.E. Optimization of a feed medium for fed-batch culture of insect cells using a genetic algorithm. Biotechnology and Bioengineering, 81 (3), 2003, pp. 269-278.

[7] Lysenko V., Chernova I. Information provision for automated production of entomophages.4th International Scientific-Practical Conference Problems of Infocommunications Science and Technology (PIC S and T- 2017), Proceedings, Vol. 2018-January, 2018, pp. 142-145.

[8] Melnichuk M., Blum, Y., Dubrovin V., Targonya V., Kolomiets Y., Belchenko V., Bespalov I.To the issue of substantiation and evaluation of bioclimatic indices of biotechnological processes on the example of the production of the enthomological drug trichogramma. J. Machinery and Technologies for Agro-industrial Complex, 8 (23), 2011, pp. 34-37.

[9] Пищанская Н.А. Усовершенствование поперечноточных аппаратов увлажнения воздуха на основе насадок упорядоченной структуры (Improvement of the cross-flow air humidification 
apparatus based on packages of an arranged structure). Пищевая Промышленность: Наука и Технология, 3 (25), 2014, pp. 57-63. (In Russian)

[10] Бельченко В.М., Піщанська Н.О., Подмазко О.С. Методика розрахунку тепло-вологісних навантажень технологічних приміщень ентомологічних виробництв (A methodology for calculation of the heat-and-humidity loads of technological premises of entomological production). Міжвідомчий тематичний науковий збірник "Механізація та електрифікація сільського господарства”, НААН України, Вип.6 (105), 2017, pp. 128-135. (In Russian) 